ASLI QoL 2021

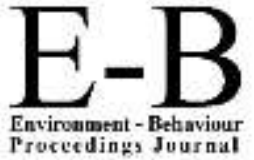

Proceeding, Juurnal

\section{AQoL2021Langkawisland}

https://www.amerabra.org; https://fspu.uitm.edu.my/cebs; https://www.emasemasresources.com/

$5^{\text {th }}$ ABRA International Conference on Quality of Life

Holiday Villa Langkawi, Langkawi Island, Malaysia, 15-16 Dec 2021

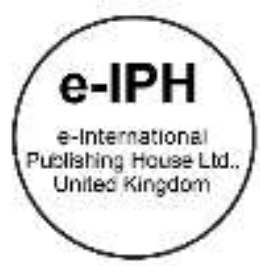

\title{
Impacts of the Japanese Middle-Class Work Culture on the Development of the Nation
}

\author{
Shalini Sanmargaraja ${ }^{1}$, Gobi Kanadasan², Naoto Mine ${ }^{3}$, Hirotake Kanisawa 4
}

\begin{abstract}
1 Department of Construction Management, Faculty of Engineering and Green Technology, Universiti Tunku Abdul Rahman (UTAR), Malaysia, ${ }^{2}$ Department of Petrochemical Engineering, Faculty of Engineering and Green Technology, Universiti Tunku Abdul Rahman (UTAR), Malaysia, ${ }^{3}$ Innovative Global Research Center, Shibaura Institute of Technology (SIT), Japan, ${ }^{4}$ Department of Architecture, School of Architecture, Shibaura Institute of Technology (SIT), Japan
\end{abstract}

shalinis@utar.edu.my, gobik@utar.edu.my, naotomine3912@gmail.com, kani@sic.shibaura-it.ac.jp Tel: +605468888

\section{Abstract}

Japanese are legendary for their workaholic nature which eventually makes Japan be super-aged country. This research aims to identify the drawbacks of their work culture towards their nation. 345 questionnaires were received using convenience sampling in Kanto and Kyushu areas. The recorded Cronbach Alpha of reliability is 0.623 , which is an acceptable level. From the descriptive analysis, is it found that the majority of the respondents strongly agree that the job stress makes them neglect their responsibilities, increasing karoshi and karojisatsu, increasing sexless marriages, and declining birth rate. The government should encourage a healthy work-life balance among the Japanese.
\end{abstract}

Keywords: Labor force, Karoshi, Karojisatsu, super-aged nation.

eISSN: 2398-4287@ 2021. The Authors. Published for AMER ABRA cE-Bs by e-International Publishing House, Ltd., UK. This is an open access article under the CC BYNCND license (http://creativecommons.org/licenses/by-nc-nd/4.0/). Peer-review under responsibility of AMER (Association of Malaysian Environment-Behaviour Researchers), ABRA (Association of Behavioural Researchers on Asians/Africans/Arabians), and cE-Bs (Centre for Environment-Behaviour Studies), Faculty of Architecture, Planning \& Surveying, Universiti Teknologi MARA, Malaysia

DOI: https://doi.org/10.21834/ebpj.v6i18.3054

\subsection{Introduction}

Japan's economy has advanced to the point where its GDP per capita now exceeds $\$ 30,000$. Meanwhile, Japan is the world's fourth-largest exporter of products and the sixth-largest importer. The majority of Japanese businesses willingly expect their employees to perform more than eighty hours of overtime per month. Due to low industrial conflict, absenteeism, and turnover, as well as great staff efficiency and high production quality, the Japanese are seen as committed employees to their companies. Every employee will be focused on the company's success. Japan will become a super-aged nation' in the coming years as a result of their loyalty and dedication to their profession." Long working hours, according to Eli (2020), are not a coincidence; rather, they are embedded in Japanese work culture. Every child's ultimate goal is to work as a salaryman. The prevalence of Japanese organizational cultures, according to Lincoln and Doer (2012), encourages paternalism or familism (kazokughugi), groupism, and vertical cohesion. When an employee uses his or her workplace to define himself rather than his or her occupation, his or her basic attitude toward his or her job shifts. The Japanese do their work not merely to make money, but also for personal fulfillment. Unlike overseas employees, domestic employees can expect to stay with the same firm until retirement. When employees fail to meet their employer's standards, they are taught to blame themselves. Since pre-war days, they have worked hard for their country because of the principle of "self-sacrifice for the country.

eISSN: 2398-4287@ 2021. The Authors. Published for AMER ABRA cE-Bs by e-International Publishing House, Ltd., UK. This is an open access article under the CC BYNCND license (http://creativecommons.org/licenses/by-nc-nd/4.0/). Peer-review under responsibility of AMER (Association of Malaysian Environment-Behaviour Researchers), ABRA (Association of Behavioural Researchers on Asians/Africans/Arabians) and cE-Bs (Centre for Environment-Behaviour Studies), Faculty of Architecture, Planning \& Surveying, Universiti Teknologi MARA, Malaysia.

DOI: https://doi.org/10.21834/ebpj.v6i18.3054 
"People who are prone to "karoshi" and "Karo-jisatsu" are called "workaholics" in Japan. Overwork-related death or a fatal sickness in humans is best defined as "karoshi" (Purnawati, 2013; Asgari, Pickar, and Garay, 2017).

According to Widarahesty (2020), the word ganbaru, which means "hard effort," defines the Japanese work culture, and employees are known for their strict work ethics and discipline, as well as their ardor and organizational skills. Nonetheless, citizens were encouraged to "sacrifice for the country" as a show of patriotism for the country to advance. Even if they leave work on time, many employees still feel bad, especially if their manager is still present. The elder generation's work ethic was impressive but impossible to replicate, with Japanese workers believing that work is their priority. As a result, the purpose of this research is to analyze the disadvantages of their work culture in terms of the nation's development.

\subsection{Literature Review}

The economy of Japan has benefited from Japan's long history of devotion and obedience. One of the results of their efforts is that they neglect their personal lives. Although Japan is a First World country, the middle class accounts for 86 percent of the population, and this tendency has been growing over the past six decades. Households in the second to fourth income quartiles are classified as middle class. Both men and women are working longer hours to compensate for the high cost of living. One of the psychological variables connected with "karoshi" and "Karo-jisatsu" is the ability to earn money, and masculinity is one of the psychological variables associated with "karoshi" and "Karo-jisatsu" (Asgari, Pickar, and Garay, 2017). According to Kamesaka and Tamura (2017), extended work hours have several negative consequences, including poor sleep quality, which leads to harmful habits such as drinking alcohol, increased karoshi and karojisatsu, increased health problems, and a reduced birth rate and aging.

\subsection{Poor sleep quality}

According to Franklin and Nakai (2017), the first notions that come to mind when thinking about Japanese corporate culture are overtime and an unhealthy work-life balance. Suicide was considered a noble deed during the feudal period of "seppuku," or samurai ceremonial suicide. According to Kubota et al. (2012), workaholic individuals may purposely create extra work for themselves by working on more projects that aren't necessary or refusing to delegate tasks. Poor sleep quality, such as insomnia symptoms, difficulty waking up, daytime tiredness or lethargy, and insufficient sleep, may be associated with workaholic distress.

\subsection{Creates unhealthy habits like drinking alcohols}

In the 1950s, it was common for salaried people to engage in behaviors such as binge drinking and chain-smoking night after night while skipping meals and sleeping. Alcohol outings, or "nomikai," have become regular and self-destructive practices, resulting in alcoholics, underweight, and sleep-deprived individuals, all of whom are classic overwork indicators. This could progress to "karoshi" if left untreated. The length of time spent at one's desk, as well as the number of hours required for mandatory office sociability, dictated how much time one worked. To put it another way, for many Japanese workers, time that should have been spent relaxing after a long day at work or simply having fun is routinely squandered by adding to body strains and anxieties (Timinsky, 2019).

\subsection{Increases "karoshi" and "karojisatsu"}

Long work hours have long been regarded as a serious social and health issue, especially in Japan (Kikuchi, et al., 2020). Karoshi is not as popular in western countries as it is in eastern Asia, according to Yang et al. (2015) and Yamauchi et al. (2017). Work-related CVDs are legalized in Asian countries due to extended working hours (Araki and Iwasaki, 2005; Takami, 2019). Karoshi has also been described as a suicide resulting from a mental disorder exacerbated by intense workplace stress. According to North and Morioka, Japanese lawyers estimate that at least 100,000 people will die each year (2016).

Employees are often denied the right to be exploited for the benefit of the corporation and the bosses' self-interest. According to Tsutsumi (2019), several experts have recommended establishing a daily minimum rest period to help people recover from exhaustion and obtain enough sleep. Karojisatsu, on the other hand, cannot be avoided just by reducing working hours unless there is flexibility for changes in the amount of work and how it is handled. Many middle-aged employees in Japan are committing suicide as a result of jobrelated stress and economic difficulty, according to Steven et al., (2019).

\subsection{Increases health issues}

Long working hours are typical in most organizations and industries, where the amount of time spent on work, including core activities, related jobs, commuting, and travel, is excessive and directly or indirectly hazardous to workers' health (Lee et al., 2007). Eli (2020) believes that appearing at work two (2) hours earlier and leaving the office five (5) hours later than their customary working hours is completely acceptable. According to epidemiological studies, long working hours are linked to an increased risk of cardiovascular disease, chronic fatigue, stress, depression, anxiety, sleep quality, all-cause mortality, alcohol, and smoking use, and self-perceived health, mental health status, hypertension, and health behaviors (Kotera et al., 2020; Wong et al., 2019; Xiao, 2019). 


\subsection{Lower birth rate and aging}

According to Tsuya (2017), Suzuki (2006), Shibata, and Raymo, Japan now has one of the world's oldest populations after more than 40 years of extraordinarily low birth rates (2017). Low birth rates mean fewer children and, eventually, fewer working-age individuals to fuel economic growth and maintain the disproportionately large number of elderly people who were born when fertility was higher. One possible cause is that young men's employment prospects are uncertain, making them poor marriage candidates.

According to Tsuji (2018), Takaki and Hibino (2014), and Kato (2018), Japanese society is concerned about sexless marriage because it is linked to long working hours and the current trend of dropping total fertility rates.

When more than $26 \%$ of the Japanese population is 65 or older, the country faces a serious aging crisis, which has reportedly increased four times in the last forty years. In the next 20 years, the Japanese labor force is predicted to shrink by $20 \%$, suggesting that more people would need to work longer hours to compensate for the labor shortage.

As seen in Fig. 1, Japan's population pyramid in 1950 was a standard-shaped pyramid with a broader bottom. The form has shrunk substantially as both the birth and mortality rates have decreased. Seniors aged 65 and older made up 35.89 million persons in 2019, accounting for 28.4 percent of the total population. According to predictions, the pyramid base will be substantially smaller in 2060 , and the total population in all age groups will be smaller.

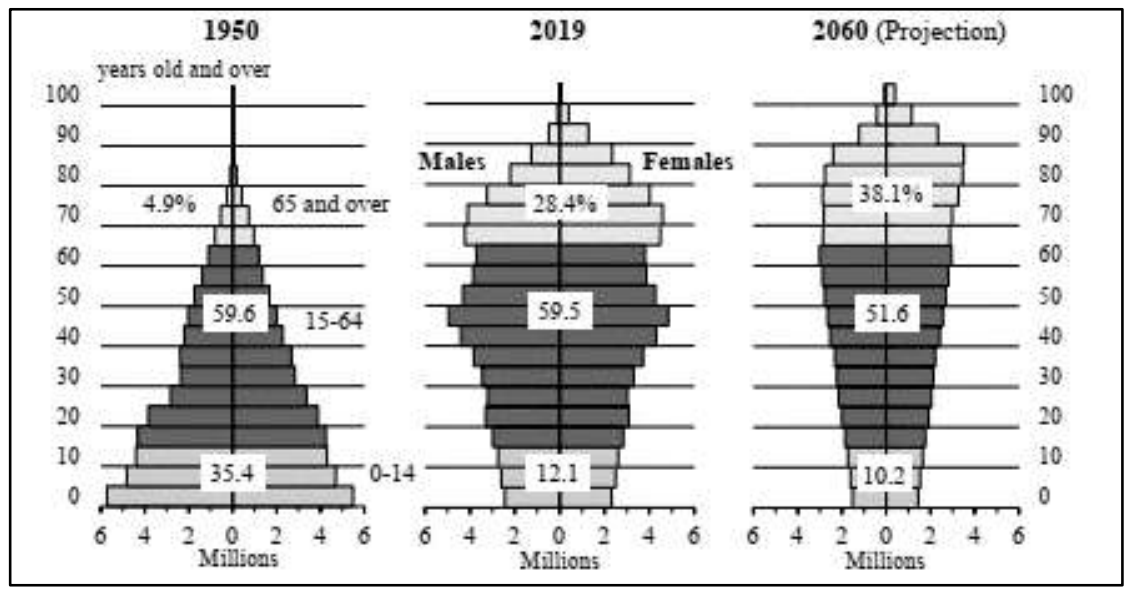

Fig. 1: Changes in the population pyramid

(Source: Ministry of Internal Affairs and Communications Japan, 2020)

\subsection{Methodology}

This study took place in the Kanto and Kyushu regions of Japan. Only 345 responses were received out of 900 sets of questionnaires delivered both physically and via Google Forms, resulting in a response rate of 38.33 percent. Since this study was conducted from October 2020 to June 2021, during the Covid 19 pandemic, few responses were obtained. Respondents were chosen using convenience sampling methods based on their availability and willingness to participate in the study. There are a few Employees in the middle class, aged 18 and up, who are the target audience for this study. Employees in general affairs, regular service employees, temporary employees, part-timers, and others with a monthly wage ranging from $0 \mathrm{JPY}$ to $600,001 \mathrm{JPY}$ are the primary focus of this study. A total of $232(67.2 \%)$ males and $113(32.8 \%)$ females agreed to take part in the study. $326(94.5 \%)$ are employed, $7(2.0 \%)$ are jobless, $7(2.0 \%)$ are looking for work, and $5(1.4 \%)$ are in other categories. $2(0.6 \%)$ were junior high school students, $34(9.9 \%)$ were high school students, $48(13.9 \%)$ were junior college students, $181(52.5 \%)$ were university students, and 80 (23.2\%) were graduate students. 57 (16.5 percent) owned a business, 238 (69 percent) worked in the private sector, 36 (10.4 percent) worked in government, and 14 (4.1 percent) worked in other occupations. $148(42.9 \%)$ of them have more than 7 years of experience, whereas $143(41.4 \%)$ of the total respondents work as regular employees. The questionnaires used in this study have four sections: Section 1 is about demography, Section 2 is about the current organization's work culture, Section 3 is about sociological impacts, and Section 4 is about the negative effects of Japanese work culture. Only Section 4 will be used for analysis in this study. In Section 4, the Cronbach Alpha values for impact from organizations and impacts on the nation are 0.720 and 0.614 , respectively, indicating adequate internal consistency, whereas the Cronbach Alpha values for impact on family and friends and impacts on the younger generation are 0.885 and 0.849 , indicating good internal consistency. Because the KMO value in Table 2 is so close to 1.0, factor analysis is appropriate for the data in this study.

Table 1. Reliability Test for Section 4

\begin{tabular}{lllll}
\hline Section & Objectives & Cronbach's Alpha & Internal Consistency & Number of Items \\
\hline $\begin{array}{l}\text { Impacts from the } \\
\text { organization }\end{array}$ & $\begin{array}{l}\text { The negative impacts of } \\
\text { Japanese work culture from } \\
\text { their organization }\end{array}$ & 0.708 & 0.720 & 10 \\
$\begin{array}{l}\text { Impacts towards the family } \\
\text { and friends }\end{array}$ & $\begin{array}{l}\text { The negative impacts of } \\
\text { Japanese working culture on } \\
\text { the society }\end{array}$ & 0.883 & 0.885 & 19 \\
\hline
\end{tabular}




\begin{tabular}{lllll}
\hline $\begin{array}{l}\text { Impacts to the younger } \\
\text { generation }\end{array}$ & $\begin{array}{l}\text { The values of life will be taught } \\
\text { to the younger generations. }\end{array}$ & 0.836 & 0.849 & 3 \\
Impacts to the nation & $\begin{array}{l}\text { The negative impacts of } \\
\text { Japanese working culture on } \\
\text { the society }\end{array}$ & 0.623 & 0.614 & 7 \\
\hline
\end{tabular}

Table 2. KMO and Bartlett's Test for Sphericity for Section 4

\begin{tabular}{|c|c|c|c|c|c|}
\hline \multirow[t]{2}{*}{ Section } & \multirow[t]{2}{*}{ Objectives } & \multirow[t]{2}{*}{$\mathrm{KMO}$} & \multicolumn{3}{|c|}{ Bartlett's Test of Sphericity } \\
\hline & & & Approx. Chi-Square & Sig & $\mathrm{df}$ \\
\hline $\begin{array}{l}\text { Impacts from } \\
\text { the } \\
\text { organization }\end{array}$ & $\begin{array}{l}\text { The negative impacts of Japanese work culture from their } \\
\text { organization }\end{array}$ & 0.887 & 1982.105 & 0.000 & 171 \\
\hline $\begin{array}{l}\text { Impacts to } \\
\text { the towards } \\
\text { the family } \\
\text { and friends }\end{array}$ & $\begin{array}{l}\text { The negative impacts of Japanese working culture on the } \\
\text { society }\end{array}$ & 0.888 & 1961.207 & 0.000 & 153 \\
\hline $\begin{array}{l}\text { Impacts to } \\
\text { the younger } \\
\text { generation }\end{array}$ & The values of life will be taught to the younger generations. & 0.702 & 472.352 & 0.000 & 3 \\
\hline $\begin{array}{l}\text { Impacts to } \\
\text { the nation }\end{array}$ & $\begin{array}{l}\text { The negative impacts of Japanese working culture on the } \\
\text { society }\end{array}$ & 0.724 & 230.140 & 0.000 & 21 \\
\hline
\end{tabular}

\subsection{Findings}

Table 3 shows the descriptive data for impacts from organizations, effects on family and friends, implications on the younger generation, and impacts on the nation. Long working hours cause waste, and inefficient human capital allocation has the greatest mean, which is around 3.623, according to the results in Table 3. Long working hours are discouraging women from contributing to the economy, and 3.530 is ranked second. The third-highest rank, around 3.348, is for Japanese employees who are under a lot of stress at work due to difficult jobs. The lowest mean score, 1.246, is for those who were penalized for leaving some tasks unfinished the next day. No time for making babies has the highest mean score of roughly 3.000 for the effects on family and friends. The second highest mean score, around 2.925 , is for failing to separate work hours from family time. The highest mean score is roughly 2.881 for those who have abandoned their aged parents owing to hectic work. The least common regret is that you feel your family is a burden, and you frequently feel nervous and regret having a family, with a mean score of roughly 1.661 . Work and climbing the career ladder are more essential to the younger generation than family, which has the highest mean score of roughly 1.528. It's acceptable to ignore responsibilities to elderly parents and to place burdens and responsibilities on your partner, both of which have a mean score of roughly 1.301. Japan, which has a low birth rate and a rapidly aging population, has the highest mean score of 4.484, indicating that its population is dropping. In Japan, many sexless marriages have the second-highest average, which is at 3.904. Karoshi and karojisatsu are becoming more popular among young people with the next highest mean score of 3.386. Many Japanese young adults under the age of 40 who have never been in a relationship have the lowest mean score, which is at 2.128.

Table 3. Descriptive analysis for the impact of Japanese work culture towards their nation

\begin{tabular}{|c|c|c|c|c|c|c|}
\hline & Item & Mean & Ranking & Median & Variance & $\begin{array}{l}\text { Standard } \\
\text { Deviation }\end{array}$ \\
\hline \multirow[t]{10}{*}{$\begin{array}{l}\text { Impacts from the } \\
\text { organizations }\end{array}$} & $\begin{array}{l}\text { Long working hours } \\
\text { produce inefficient } \\
\text { human capital }\end{array}$ & 3.623 & 1 & 4.000 & 1.320 & 1.743 \\
\hline & $\begin{array}{l}\text { Long working hours } \\
\text { push away women }\end{array}$ & 3.530 & 2 & 4.000 & 1.301 & 1.692 \\
\hline & Faced high pressure & 3.348 & 3 & 4.000 & 1.227 & 1.507 \\
\hline & $\begin{array}{l}\text { Karoshi is mostly } \\
\text { caused by strokes, } \\
\text { heart attacks, and } \\
\text { even willful starvation. }\end{array}$ & 2.968 & 4 & 3.000 & 1.343 & 1.803 \\
\hline & $\begin{array}{l}\text { Being pressurized to } \\
\text { fit-in in the } \\
\text { organization }\end{array}$ & 2.728 & 5 & 3.000 & 1.207 & 1.457 \\
\hline & Always skip meals & 2.241 & 6 & 2.000 & 1.463 & 2.143 \\
\hline & $\begin{array}{l}\text { Hardly get positive } \\
\text { employer feedback }\end{array}$ & 2.186 & 7 & 2.000 & 1.154 & 1.332 \\
\hline & $\begin{array}{l}\text { Existence of seniority } \\
\text { system }\end{array}$ & 2.046 & 8 & 2.000 & 1.154 & 1.332 \\
\hline & $\begin{array}{l}\text { Avoid taking paid } \\
\text { annual leaves }\end{array}$ & 1.939 & 9 & 1.000 & 1.176 & 1.383 \\
\hline & $\begin{array}{l}\text { Penalized for leaving } \\
\text { some unfinished task }\end{array}$ & 1.246 & 10 & 1.000 & 0.652 & 0.425 \\
\hline \multirow[t]{3}{*}{$\begin{array}{l}\text { Impacts towards the } \\
\text { family and friends }\end{array}$} & $\begin{array}{l}\text { No time for making } \\
\text { babies }\end{array}$ & 3.000 & 1 & 3.000 & 1.574 & 1.962 \\
\hline & Fail to segregate time & 2.925 & 2 & 3.000 & 1.439 & 1.803 \\
\hline & $\begin{array}{l}\text { Abandoned old } \\
\text { parents }\end{array}$ & 2.881 & 3 & 3.000 & 1.321 & 1.745 \\
\hline
\end{tabular}

32 


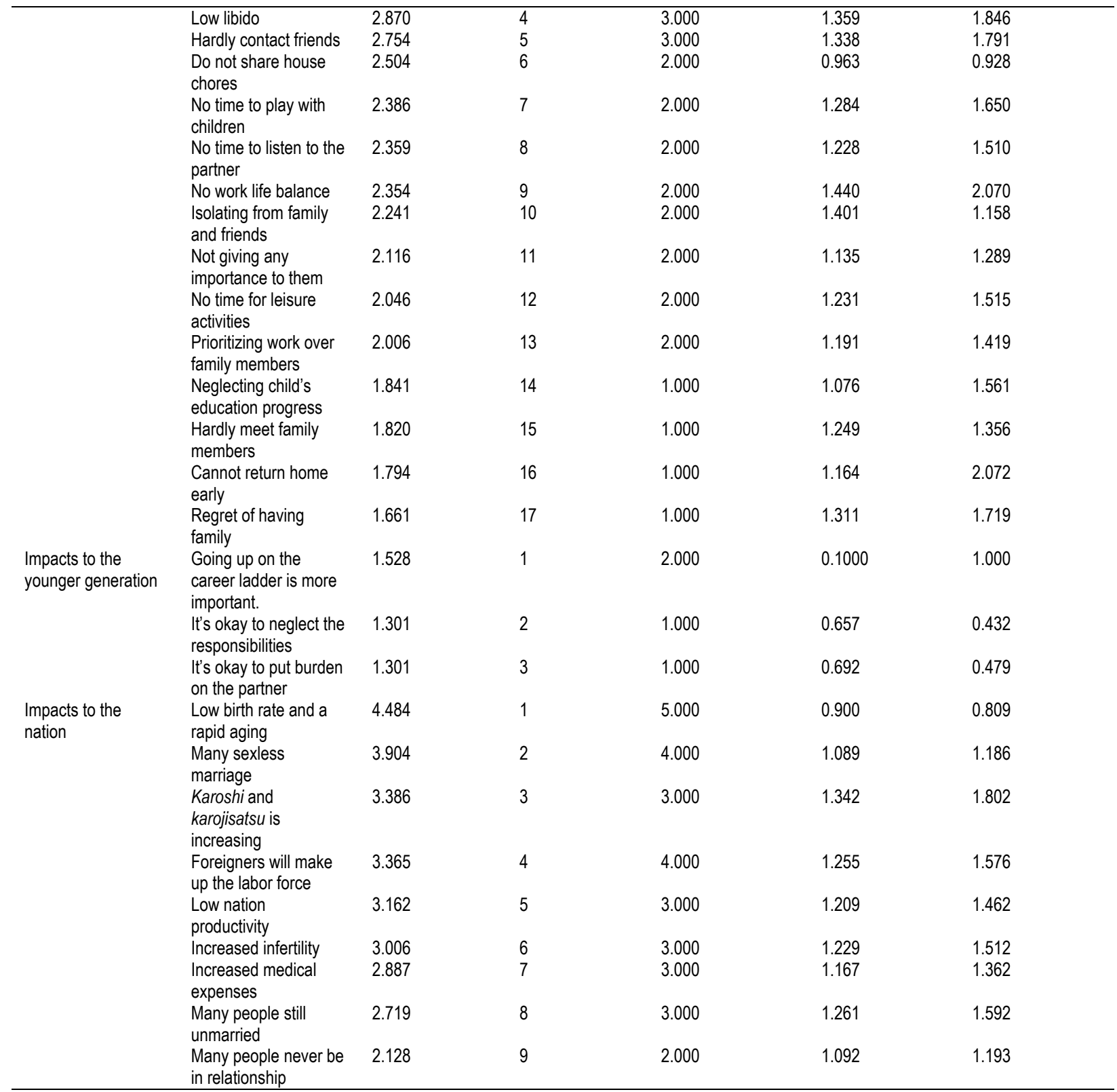

\subsection{Conclusion \& Recommendations}

To summarise this paper, the mean score for long working hours producing waste and inefficient human capital is around 3.623 , followed by long working hours discouraging women from contributing to the nation's economy, which is 3.530 , followed by Japanese employees who are usually under pressure, which is around 3.348 , and penalized for leaving some tasks unfinished for the next day, which has the lowest mean score of 1.246 for organizational impacts. For the impacts on family and friends, the highest mean score is around 3.000 , followed by failing to separate work hours and family time, which is around 2.925 , abandoned their elderly parents due to busy work, which is around 2.881, a regret of feeling that your family is a burden and you often feel nervous, and regret having a family, which is around 1.661. Work and climbing the corporate ladder are more important than family, with a mean score of 1.528 , followed by it's okay to ignore responsibilities to elderly parents and it's okay to place burdens and responsibilities on your partner, with a mean score of 1.301 for the effects on the younger generation. Japan has the highest mean score, which is about 4.484, followed by many sexless marriages in Japan, which is about 3.904, increased Karoshi and karojisatsu among young adults, which is about 3.386, and many Japanese who never had any relationship until the age of 40 , which has the lowest mean score, which is about 2.128 for the nation's impacts.

So that women can contribute to the nation's economy, the Japanese government should tighten the laws governing extra working hours and implement new policies on early child care. In addition, the government should recognize compliance firms for following the most recent standards in terms of tax exemptions, supplementary leave policies, and other measures to encourage Japanese workers to maintain a healthy work-life balance. Although many alternatives can be implemented, things do not change overnight, therefore small modifications can make a big difference in improving the quality of life of the Japanese. The data collection for this study was done during the Covid-19 outbreak, which is a drawback. As a result, several respondents were hesitant to participate in this research, and some were 
terrified to participate for fear of being reprimanded by their employers for reporting against their regulations. More research replicating the work culture in American, European, and other ASEAN countries would be required, as the data gathered from this study cannot be utilized to generalize the work culture of the entire Japanese population.

\section{Acknowledgements}

My sincere appreciation and thanks to The Sumitomo Foundation for providing the funding and support for this research under the Reg. No. 199489. Thank you.

\section{Paper Contribution to Related Field of Study}

This research will contribute to the body of knowledge under the workplace environment.

\section{References}

Asgari, B., Pickar, P. and Garay, V. (2016). Karoshi and Karao-jisatsu in Japan: Causes, Statistics and Prevention Mechanism. Asia Pacific Business \& Economics Perspectives, 4(2), 49-72.

Araki, S. and Iwasaki, K. (2005). Death due to Overwork (Karoshi) Causation, Health Service and Life Expectancy of Japanese Males. JMAJ. $48(2), 92-98$.

Eli, C. (2020). Work Hours in Japan: The Dedicated Working Culture in Japanese Society. Retrieved from https://japanyugen.com/work-hours-in-japan-the-dedicatedworking-culture-in-japanese-society/ on September 10, 2020.

Franklin, S. and Nakai, Y. (2017). Japanese Business Culture: A study on Foreigner Integration and Social Inclusion. Honors Theses. 1-477. Eastern Kentucky University, United States.

Kato, H. (2018). The Analysis on Disparities of Fertility Rate of Japanese Municipalities. Public Policy Review. 14(1). 1-24.

Kikuchi, H., Odagiri, Y., Ohya, Y., Nakanishi, Y., Shimomitsu, T., Theorell, Inoue, S. (2020). Association of Overtime Work Hours with Various Stress Responses in 59,021 Japanese Workers: Retrospective Cross-Sectional Study. Retrospective Cross-Sectional Study. PLoS ONE. 15(3), 1-22.

Kotera, Y., Laethem, M.V., Ohshima, R. (2020). Cross-Cultural Comparison of Mental Health between Japanese and Dutch Workers: Relationships with mental Health Shame, Self-Comparison, Work Engagement, and Motivation. Cross-Cultural \& Strategic Management Journal. 27(3), 511-530.

Kubota, K., Shimazu, A., Kawakami, N. and Takahashi, M. (2012). Workaholism and Sleep Quality Among Japanese Employees: A Prospective Cohort Study. International Journal of Behavioral Medicine. 19(4), 1-13.

Lee, S.; McCann, D.; Messenger, J.C. (2007). Working Time Around the World. The trend in Working Hours, Laws and Policies in a Global Comparative Perspective; International Labour Office: Geneva, Switzerland.

Lincoln, J.L. and Doer, B. (2012). Cultural Effects on Employee Loyalty in Japan and the U.S: Individual or Organization Level?

Ministry of Internal Affairs and Communications Japan. (2020). Statistical Handbook of Japan. pp. 1-213. Retrieved from https://www.stat.go.jp/english/data/handbook/c0117.html on September 12, 2020.

North, S. and Morioka, R. (2016). Hope Found in Lives Lost: Karoshi and The Pursuits of Worker Rights in Japan. Contemporary Japan, 28 (1), $59-80$.

Purnawati, S. (2013). Current Issues on Job Stress in Japan and Worksite Mental Health Application Among Japanese Company: Case Study Analysis. Bali Medical Journal (BMJ), 2(2), 81-88.

Suzuki, T. (2006). Fertility Decline and Policy Development in Japan. The Japanese Journal of Population. 4(1). 1-32.

Raymo, J.M. and Shibata, A. (2017). Unemployment, Non-Standard Employment, and Fertility: Insights from Japan's Lost 20 Years. Demography. 54(6). 2301-2329.

Steven, D., Targum, M.D., and Kitanaka, J. (2019). Overwork Suicide in Japan: A National Crisis. Innovations in Clinical Neuroscience. 9 (2), $35-38$.

Takaki, J. and Hibino, Y. (2014). Family-Related Opinions and Stressful Situations Associated with Psychological Distress in Women Undergoing Infertility Treatment. International Journal Environmental Research and Public Health. 11. 9068-9081.

Takami, T. (2019). Current State of Working Hours and Overwork in Japan: Part III: How Can We Prevent Overwork? Japan Labor Issues. 3(19), 25-29.

Timinsky, S. J. (2019). The Nation that Never Rests: Japan's Debate Over Work-: Life Balance and Work that Kills. The Asia-Pacific Journal. 17(10), 1-16.

Tsuya, N. O. (2017). Low Fertility in Japan-No End in Sight. Asia Pacific Issues. 1-4.

Tsutsumi, A. (2019). Preventing Overwork-Related Deaths and Disorders-Needs of Continuous and Multi-Faceted Efforts. Journal of Occupational Health. 61(4), 265-266.

Widarahesty, Y. (2020). Otsukaresamadeshita!: A Critical Analysis of Japan's Toxic Work Culture, International Journal of East Asian Studies, 9(1), 32-47. 
Xiao, N., Yang, B.F., Shi, J.Z., Yu, Y.G., Zhang, F. Miao, Q. and Li, D.R. (2019). Karoshi May Be a Consequence of Overwork-Related malignant Arrhythmia. Med Sci Monit, $25,357-364$

Yamauchi, T., Yoshikawa, T., Takamoto, M., Sasaki, T., Matsumoto, S. Kayashima, K., Takeshima, T. and Takahashi, M. (2017). Overwork-Related Disorders in Japan: Recent Trends and Development of a National Policy to Promote Preventive Measures. Industrial Health., 55, 292-302.

Yang, Z. Yang, B. and Li, J. (2015). Perspectives on Compensation and Legislation on Death due to Work Overload-Karoshi. An International Journal of Medicine, 108 (4), 349-350. 